\title{
On not researching school leadership: the contribution of S. J. Ball
}

\author{
Helen M. Gunter* \\ School of Education, University of Manchester, Manchester, UK \\ (Received I8 February 2013; final version received 6 July 2013)

\begin{abstract}
Stephen Ball's research continues to make a contribution to describing, understanding and explaining the political, social, economic and cultural context in which educational professionals locate their practices. Therefore, Ball engages with issues about school leadership, but he does not set out to present solutions for school leaders. Based on critical reading and interview data, I show how by not researching school leadership he makes a robust and relevant analysis of school leadership for the profession. He makes a contribution to understanding the realities of doing and thinking about leaders doing leadership and exercising leadership, where his starting point is to work with the profession as public intellectuals.
\end{abstract}

Keywords: Ball; leadership; education policy; knowledge production; Bourdieu; policy studies

\section{Introduction}

Stephen Ball does not research school leadership. Or more precisely he does not set out to construct and popularize best practice leadership models for professionals to be trained to apply as solutions to problems that are not necessarily their problems or at least their problems alone. The indexes to his books rarely have leadership as an identified category. In his own words: 'I don't think that l've written anything that anybody has ever found useful in any practical sense ... I don't want to tell people what to do, but I want to help them to think about what they do' (Gunter, 2006a). Ball's contribution is to enable the profession to understand that the situation they are in may not be of their making, and as such practice is socially, economically and politically constructed. Consequently, he locates and inhabits field territory that begins education policy work on the basis that professionals are 'public intellectuals' where he argues: 'I don't have any ambition to say this is what your school should look like if its going to be a good school, but what I would like ... to think that I contribute to in some cases is to offer some people some tools that enable them to construct a good school, in terms of the way they think about things, the way they address problems, the way they analyse ways forward, deconstruct problems' (Gunter, 2006a). So Ball makes a contribution rather than provides a template, he expresses through narrative rather than in bullet points, he speaks with those who are ready to engage rather than to those who think they must perform, and he interrupts through ideas rather than operates the levers of modernization. In doing so, his work is globally recognized, cited and used by policy scholars but is largely ignored by the 'effectiveness' and 'improvement' school leadership field.

\footnotetext{
*Email: helen.gunter@manchester.ac.uk 
For over 30 years, Ball has produced an impressive body of work that is methodological (Ball 1994c; Maguire and Ball 1994a), empirical (Ball 198I), conceptual (Ball 1990b, 2013), and discursive (Ball 2004a) and has focused on policy processes in relation to the curriculum (Goodson and Ball 1984), workforce (Ball 1990a; Ball and Goodson 1985; Maguire and Ball 1994b), the school system (Ball 1984), the school as an organization (Ball 198I; Bowe and Ball 1992), and the way markets and social class impact (Ball 2003a; Gewirtz, Ball, and Bowe 1995). Importantly, he has helped to establish and shape critical education policy studies as a field of research and activity, through studies of major reform interventions (Ball 2005, $201 \mathrm{la}$; Maguire, Ball, and Braun 2012) and debates about the configuration and purposes of policy scholarship (Ball 1990a, 1994b, 1995, 1997, 2006, 2008a, 2008b). Much of this is fertile ground for Ball to at least bump into school leadership, even if he does not set out to directly study it. As such my task in examining the influence of his work could be rich in data and conceptual meaning, but it could also be dangerous where I grant 'the canonical texts the false eternalization of ritual embalming' (Bourdieu 2000, 48). Indeed, through occupying similar epistemological territory, I may misrecognize the way 'scholastic fallacy' (Bourdieu 2000, 49) operates in knowledge production, particularly in the narrating of a particular knowledge producer's contribution to knowledge and knowing in policy studies. I intend handling this in two broad ways: first, through drawing on my critical reading of Ball's location in the field of leadership studies (see Gunter 20I2a), and having gained his permission to use the oral text produced for the Knowledge Production in Educational Leadership project I use his voice to publicly speak to the issues raised (Gunter, 2006a); and second, through using an approach to the conceptualization and writing of intellectual histories where methodologically I have undertaken technical, critical and positional analysis to compose a critical narrative (Gunter 2006b).

\section{Not school leadership}

Ball tells the following story:

I remember last year I gave a talk about performativity, l'd written some things about performativity in education to a very mixed group of people including teachers and students, and afterwards a woman came up to me and said 'thank you, thank you very much for that. I resigned as a teacher last year', and she said 'now I know why I resigned'. And although in a sense that's a sort of negative example I was very pleased with that because I think what she was saying was that she had the tools to make sense of her experience ... she went onto elaborate, she said 'emotionally I couldn't cope anymore. I found what was happening to me abhorrent', and I think what she was suggesting was she hadn't been able to analyse it intellectually, and she now knew why she had made the right decision from her point of view. On Saturday, I hosted a conference here on secondary schools, which was a reaction to the White Paper and Education Bill, and lots of interesting people spoke, and one person was [Name], who's head of a school in [Place], and I taught him when I was at [Place], he was one of my MA students, almost all of my students went on to be head teachers ... and he was saying to me before we started, he still thinks about that course he did at [Place] in the late 1970s and it still gives him tools that he says are still useful. And its those things that I think are important. (Gunter, 2006a)

This story illuminates how Ball is concerned with the conditions in which professionalism and professional work are constructed, and the way professionals can be enabled to give meaning to it. In doing so, he acts as a public intellectual and he embraces the professional as a public intellectual, not least through how knowledge production can be democratized within the exchange relationships that he describes in the above encounters. For Ball the education professional is not a 'saintly' carer but neither the self-interested 'devil' often portrayed in policy texts; the professional is struggling for an educational identity, with a strong sense of agency rooted in educational values. But the professional has had 
managerialist processes imposed upon them in ways that induce 'terror' (Ball 2003b), where there is a need for researchers to document and create understandings, rather than valufacture salvation narratives. Professionals who engage with such research, particularly through postgraduate study, can develop and use their learning in ways that are enduring and enabling. There are no quick fixes in Ball's world. Importantly, this also enables the need for the professional to be simultaneously attached and detached in relation to practice: attached in the sense of always located within the purposes, rationales, narratives and necessities of teaching and learning, but also detached through the opportunity to think and talk and act about such attachment (Gunter 20l2b).

So Ball has, in his own words, 'never set out to study heads' (Gunter, 2006a), but what he has done, and continues to do, is to work with them to collect accounts of professional practices at a time of rapid modernization. He has reported on a range of projects and here I intend presenting a few examples:

198 I: Beachside Comprehensive, A Case Study of Secondary Schooling (Ball 1981): based on ethnographic participant observation, the focus is on examining internal innovation regarding student grouping where the staff voted for change, but where the 'role of the headmaster as opinion leader was crucial in giving the original drive to the innovation'. (169)

1987: The Micro-Politics of the School, Towards a Theory of School Organization (Ball 1987): based on interviews, the focus is on schools as 'arenas of struggles' (Ball 1987, 19), where a detailed analysis is given of the relationship between headship identity and doing headship work, and the politics of leadership through an examination of the way power works, not least through 'leadership styles'.

1992: Reforming Education and Changing Schools, Case Studies in Policy Sociology (Bowe, Ball, and Gold 1992): based on interviews and policy texts, the focus is on the change management required through site-based management from 1988, and the realities of internal change processes through which external innovations such as the national curriculum 'is not so much being 'implemented' in schools as being 're-created', not such much 'reproduced' as 'produced' (Bowe, Ball, and Gold 1992, 120). In finding and creating such spaces for professional and contextual agency, the conclusion is drawn that 'for better or worse, in most schools the Head remains the 'critical reality definer' (Bowe, Ball, and Gold 1992, 172), where mediation is clear to understanding position taking.

1993: Values and ethics in the education market place: the case of Northwark Park (Gewirtz, Ball, and Bowe 1993): based on interviews, observations and texts from a larger project about how local markets work, the focus in this paper is on how the staff and governors 'want to hang onto their principles, to the comprehensive ethos, whilst becoming more successful in the market place' (Gewirtz, Ball, and Bowe 1993, 239), and where the head teacher is identified as operating 'as the point of interface between the old and the new values'. (Gewirtz, Ball, and Bowe 1993, 240)

1994: Education Reform, A Cultural and Post-Structural Approach (Ball 1994a): based on interviews and policy texts, the focus is on how site-based management from 1988 created and required a 'new' form of headship with new relationships and cultures generating head teacher positions as 'hawks', 'doves', and 'agnostics' in relation to school competition and choice.

20 12: How Schools Do Policy, Policy Enactments in Secondary Schools (Ball et al. 2012): based on in depth case studies of four schools using interviews, observations and texts, the focus is on how policy is enacted in ways that are 'dynamic and non-linear' (Ball et al. 2012,6) and where a range of actors are involved in the large number and complex demands of external policy requirements. Importantly heads and senior leaders are actively involved in handling the external demand for and construction of the good pupil, teacher, school, where data determines identity and practices in the market place.

This brief overview of selected projects generates some important thematic trends over time: first, an enduring focus on the realities of work and the construction of professional 
identities through the interplay of agency and structure; second, a critical encounter with power processes within organizational relationships, and how position taking by the individual and positioning by other actors works in complex and often unclear ways; third, the way that external and internal organizational change models interplay through professional practice; fourth, the production of intellectual tools regarding power process within internal and local policymaking to enable thinking and decision-making. In doing this, Ball not only gives voice to the profession but also seeks to relate it to performativity (Ball 200la) and markets (Ball 2007, 2012). Importantly, he questions whether the agency imposed on heads as entrepreneurs in the new market place is authentic or not, whereby through examining the relationship between heads and governors he states: 'we may perhaps no longer be asking whether the head is a good leader, but whether he or she is the leader at all' (Ball 1994a, 88). His forensic focus on policy texts and the realities of handling competing and usually contradictory reforms also leads him to the conclusion that '... on the one hand, the head teacher is a key figure in the process of reform. But on the other, the Conservative government is deeply suspicious of professional expertise in any area of public service' (Ball 1994a, 89). This is probably Ball's most important contribution to the school leadership field.

Ball has given insights into professional identity formation and development through his work on markets, and how neoliberalism requires local reform deliverers to be enthusiastic about responsibilities exercised through new enterprise knowledge (see Ball and Exley 2010). From the 1980s, he does this through a critical analysis of growth of management in the self-managing school:

Self-management is a key to the achievement of 'steering at a distance'; it articulates self-regulation with a microtechnology of control and ramifies the value and cultural changes set in train by finance-led decision-making and competition. In other words, it is a disciplinary practice. But as a discourse, management is productive rather than simply coercive. It increases the power of individuals - managers and managed in some respects - while making them more docile. Management is both a body of precepts, assumptions and theory, to be learned by managers, and a set of practices to be implemented, encompassing both managers and managed'. (Ball 1993, 66)

And from the 1990s onwards, he shows how leadership has overlain this, interplayed with the promise of agency, so that the profession can grasp the requirements of global capital:

\begin{abstract}
Leadership and enterprise are ... a means of interjecting practical innovations and new sensibilities into areas of education policy that are seen as change resistant and risk averse. More generally they 'pilot' and disseminate as 'good practice' the conditions (strategic and discursive) for a 'post-welfare' education system in which the state contracts and monitors but does not deliver education services - metaheterarchy - thus creating new opportunities for profit' for the private sector or social entrepreneurs or voluntary organisations. (Ball 20I2, 35-36)
\end{abstract}

In this sense, the claims for and about leadership made in policy texts (e.g. DfEE 1998) and by influential leadership gurus (e.g. Leithwood, Jantzi, and Steinbach 1999) that leadership is empowering, about local vision and mission through which vital changes, is shown to be something different: 'leadership is a means of reworking and narrowing the responsibilities of the practitioner by excluding 'extraneous' issues that are not directly connected to performance outcomes' (Ball 20I2, 34). Those given the title leader, the job description of leading, and the requirement to exercise leadership, do what is needed to secure reforms, where deeper professional values and wider interests are eliminated as unmodern. In this sense, 'the new school leader embodies policy within the institution' (Ball 2008a, 140), and while under New Labour (1997-2010), this was about self-regulation as a means of 
delivering national standards, under the Conservative led Coalition from 2010 this is about self regulation as a means of fabricated autonomy in delivering national standards.

How this happens within the realities and often irrationalities of professional practice is difficult to map and examine, not least that market savvy moves are not necessarily open to empirical capture, but the case is made that 'within the public services, the effects of privatization, commodification and market forces are ineluctable, not just in terms of a mechanism of reform, but in terms of the possible forms of self that are make available to us' (Ball 2004b, 7). Ball (2010) uses Ozga (2009) and colleagues work on 'governing knowledge' (Ball $2010,264)$ to examine how targets and statistics govern the person:

performativity 'works' most powerfully when it is inside our heads and our souls; that is, when we monitor and manage ourselves, when we take responsibility for working harder, faster and better, thus 'improving' our 'output', as part of our sense of personal worth and in the ways we judge the worth of others. (Ball 2010, I25)

Leadership as a knowledge technology is examined in Ball's recent work, whereby he has studied the 'commercialisation and commodification of this leadership knowledge' (Ball 20l0, 127). He distinguishes between 'knowledge about' education through evaluations, inspections and league tables, and 'knowledge for' modernized conduct within new structures and cultures, not least through how 'the teacher is 'hailed' as a leader' (Ball 2010, I28). In spite of the rhetoric otherwise, this is not evidence based but is a form of marketized commonsense, an almost revelatory post-political process; there is nothing to debate because leadership is normal, it works well in business, and so the only issue is about effectiveness and improvement.

In scoping the knowledge workers in policy governance networks, Ball and Junemann (2012) show how leadership training is being designed and used to bring this about. Future Leaders is a New Labour training programme for heads of schools in disadvantaged areas, and has continued under the Coalition, and for Ball it illuminates how the new school leader is not only a product of state controlled self-regulation but also new partnerships between the state and private interests and philanthropic organisations. He notes the importance of ARK (Absolute Return for Kids) in the Future Leaders and other interventions into training and service delivery, where the argument is made:

ARK therefore plays a significant role in the process of public sector transformation ... whereby a variety of new organisations working in different relations to the state take up positions and roles previously reserved to the state itself and through which new practices and methods are brought to bear upon education problems, changing the way in which these problems are addressed. (Ball and Junemann 2012, II3)

Such insights enable him to move forward in developing a better way to conceptualise policy processes, whereby he is working for a shift from the intellectually barren implementation studies towards liquidity at the interface of global, national and local policymaking (see Reay and Ball 2000). He is more interested in the interstices where policy ideas and texts are struggled over and produced, and as such his conceptual tools are ones that seek to reveal this, and examine the potential damage that policy 'deliverology' (Barber 2007) can do to professionality. It seems that localized policymaking is seen as damaging to the centralising agenda, and so policy intentions and planned outcomes must be 'delivered' to children without interference. The more that the realities of professional practice are opened up for scrutiny the more convincing is his analysis, not least the recognition that the claims for autonomy and agency are in reality new forms of 'subordinate leadership, that is, the chain head or what we might call the corporate head, or head teacher appointed by a sponsor' (Ball 20llb, 5l). In this sense, he is critical of knowledge production within both policy 
science because of the emphasis on securing and measuring fit, and policy entrepreneurship because of the development of leadership products for sale to the profession (Ball 1995). Let me say some more about this.

\section{Not doing effectiveness and improvement}

In my scoping of the leadership terrain and knowledge production during the New Labour governments from 1997 I located Ball's work within what I called a Policy Research Regime (PRR) (Gunter 20I2a). By this I mean field members who locate studies within and about schools in ways that relate required practices on a Monday morning with theories of power and wider social justice analysis. So claims about the potency and necessity of effective and improving school leadership are scrutinized through inter-relating with debates about the purposes, rationales and narratives of education, not least through challenging the dominance of neoliberalism and neoconservatism, and identifying attacks on civic or welfare systems (Gunter et al. 2010). In this sense Ball inhabits similar territory as other UK-based policy scholars such as Gewirtz, Grace, Ozga, Thomson, and international researchers such as Apple, Bates, Blackmore, Lingard, Rizvi and Smyth. This community cannot be homogenized, not least because they debate knowledge claims, and through the development of education policy sociology Ball has countered the challenge from Marxist critiques (see Ball 1994d; Hatcher and Troyna 1994). He has responded to charges that his work feeds reformism, particularly through a concern that while the state is powerful he shows that he is 'unhappy with the totalitarian vision of the state and the disempowerment of 'ordinary' social actors which that involves' (Ball 1994d, 172), Ball (1994d) does this by making two valuable points: (a) that not all professional practice is 'defined solely within the stultifying parameters of policy' (Ball 1994d, 177); and, (b) researching professional practice has itself to be developed, and he makes a case for 'a sociology of complexity, uncertainty and doubt' (Ball 1994d, 180). Therefore, and to varying extents, he would share the concerns of the critical policy community about the impact of welfarism and neoliberalism on schools (Gewirtz 2002), leadership (Grace 1995) and the profession (Ozga 2000). Within this community, there is a commitment to frame and develop critical policy studies and to develop conceptualizations of governance in ways that are simultaneously international and local (Apple 2010; Rizvi and Lingard 2010). This community is concerned to reveal the way that managerialism has impacted on professional values, integrity and practice, and there is much that Ball would agree with in regard to the construction of school leadership as a form of policy conceit, particularly its contribution to the endurance and acceptability of social injustices. Where Ball is distinctive is through a research emphasis on the profession rather than children, through the sociology of the school as an organization rather than through descriptions of classroom activity, and through the use of conceptual tools from sociology and political science in order to think about methodological synergies between education and public policy (Ball 200 Ib, 2008c, 2009).

While Ball's work is a cynosure for many critical policy scholars, and those who have sought to locate specifically as critical leadership researchers, his influence on 'improvement' and 'effectiveness' school leadership studies is limited to the odd decorative reference (e.g. Day et al. 2000; Stoll and Fink 1996). Like Ball, those who locate within school effectiveness and school improvement (SESI) studies examine the school as an organization, and how professional practice happens and might happen in ways that bring about important changes to student achievement and aspirations. However, unlike Ball, they have focused on school leadership as a functionally descriptive and functionally normative process, and so they have sought to present evidence informed models of good practice, and when the evidence has 
been wanting in terms of sufficiency and rigour they have sought to advocate for models of best practice (see Gunter, Hall, and Bragg, 2013). For example, Ball has produced accounts of the realities of organizational decision-making in ways that could be called 'distributed leadership' (see Ball et al. 2012; Bowe, Ball, and Gold 1992), but this is not the form of distributed leadership that dominates functional discourses (e.g. Harris 2008). Consequently key texts as intellectual markers in SESI field scoping (e.g. Hopkins 2007; Teddlie and Reynolds 2000), as enabling professional practice (Leithwood et al. 2006), and as informing policy implementation (e.g. Hopkins 200I), do not include his work. Indeed, Ball has sought to distinguish his position from this community, where he identifies Hargreaves and Hopkin's (I99I) text The Empowered School as 'the acceptable face of management':

This approach is very process-oriented; it is value-free, content-free management (in the sense that good practice is entirely a matter of process). It is the management of anything or nothing (and this is profoundly disturbing). It divorces management practices from values and from politics. The book also has only one index entry for 'values'. It is technically oriented, rational and apolitical. There are no index entries for 'conflict'. This is management in the best of all possible schools. It is anodyne and reassuring and does a great deal to legitimate management to the professional audience. (Ball, 1993, 67)

This type of work is located in what I have identified as government regimes, whereby between 1997 and 2010 the SESI communities located within the New Labour Policy Regime and from 2010 in the Conservative Market Regime. Here, researchers and policymakers engage in exchange relationships regarding the interplay between reform strategy, investment and status. Such position taking is related to a number of complex factors: first, the public link between evidence from school effectiveness and investment by government (Barber 1996; Creemers, Scheerens, and Reynolds 2000); and second, espoused partnerships between researchers and policymakers (Reynolds et al. 1996; Sammons et al. 2010). Ball is concerned about such position taking, where he labels the 'safe, fictive revolutionism that remains a la mode in some parts of the academy' (Ball 1998, 82), as a product of 'textual apologists' (Ball 1993, 79), where SESI knowledge workers generate new markets for their products:

... where there is illness there is also 'cure', models of 'effective practice'. If self-examination fails, the expert, the authority, the consultant, the moral disciplinarian is at hand to intervene. In effect, given the logic of management, ineffectiveness is seen as a disorder of reason and as such susceptive to cure by the use of appropriate techniques of organization'. (Ball 1990c, 164)

This critique is one that is familiar (see Gunter 1997), and importantly, it is one that the SESI community rarely give recognition to or engage with. When they do reply then the case is made that there are differences that help to shape thinking but ultimately the two positions are irreconcilable (e.g. Teddlie and Reynolds 200I). Young's (2008) analysis is helpful as he distinguishes between knowledge that is 'theoretical' and 'political', and this has resonance within of the field of school leadership whereby Hoyle (1986) talked about 'knowledge for action' and 'knowledge for understanding': it seems that Ball is concerned with how the former is informed and enabled through the latter, whereas SESI is concerned with how the former is not prevented by the latter. This seems to be because of an approach to knowledge production where purposes and methodologies are different. For example, Teddlie and Reynolds (200l) describe themselves as 'pragmatists with an action oriented, mixed methods research agenda aimed at changing schools as they currently exist' (Teddlie and Reynolds 200I, 76), and while they have selectively used the criticisms to support field development, there is irritation at the critical 'myopic' requirement to debate knowledge claims (Teddlie and Reynolds 200I, 76). Ball takes a different position: 
I have a sort of perverse pride in being a sociologist. You know, 'my name is Stephen Ball and I am a sociologist'. I think for me the important virtue of sociology as practice is rigour ... what I try to do in my work is move in a creative but productive way between research and theory, between data and theory, to inform data with the interpretive frameworks offered by theoretical possibilities, but also to ... challenge theory with data. And I find that tension very powerful and productive. (Gunter, 2006a)

Ball goes on to argue that social scientists cannot be neutral, and as part of the world they need robust frameworks to provide meaning and explanations: 'if you deny the interpretive aspects of practice, then I think you are giving away reflexivity and your practice is damaged by it. So, sociology provides me with my intellectual tools really for dealing with the world' (Gunter, 2006a). Such sociology enables serious questions to be asked about Teddlie and Reynold's focus on 'changing schools as they currently exist', not least how this has value in the exchange relationships within government regimes. Furthermore, it enables researchers such as Angus (1994) to provoke the critical policy researchers into understanding why SESI texts are popular with government and practitioners, not least because they purport to address the key issues that have been identified as vital to children's learning. He identifies Ball's work as integral to how sociological analyses actually do speak to these issues without sacrificing scholarship. It is nearly twenty years since Angus' paper, and so there could be a need for the PRR to engage with how and why there remains an enduring disposition by professionals to seemingly accept policy science and buy into entrepreneurship than there is to engage with a public intellectual role associated with policy scholarship. Or it could be, as Ball states in the quotes I have used in the introduction to this paper, such encounters are necessarily private, and when public they tend to be through postgraduate study and post graduation networking.

Importantly, the relationship between research and professional practice generates a range of debates that the community that Ball is located within are discussing: first, Gamble's (20I2) reply to Chakrabortty's (20I2) critique of social science research and its failure to respond to the banking crisis is helpful, not least his argument that the relationship between ideas and action is an issue that research users and not just producers need to engage with; second, professionals do challenge policy deliverology (e.g. Evans 20I3; Millar 2013) in ways that open up opportunities for public intellectual activity, and so there is an issue of who the profession turn to for help when they do this. It seems to me that there is an appetite for the type of knowledge production that Ball and colleagues engage with, not least that when the professionals I work with engage with critical policy ideas they tend to become very angry that leadership training has presented them with unworkable solutions and denied them access to more productive thinking. In Bourdieu's terms, Ball is an antidote to Le Fast Talkers who marketize leadership as a commodified product (see Gunter 20I2b), particularly how he reveals and confronts the dilemmas and tensions in doing the job, and how intellectual work is core to how professionals engage with such realities. Ball himself recognizes that in a modernizing education system his analysis could be deemed 'luddite' (Ball 1990c), but there are enough professional researchers and researching professionals on the same terrain to demonstrate that his analysis of modernization is convincing and enabling. What Ball does is to make his contribution to this as clear as is possible, not least that it is necessarily a focused and unfolding one. Importantly, he shows that we do not need to focus on school leadership in order to understand and explain what it means to practice school leadership. And, by not researching school leadership he enables professionals and researchers to have access to a range of data and thinking that is enriching and relevant to intellectual work and hence professional practices. 


\section{Acknowledgements}

I would like to thank Stephen Ball for giving me permission to use the interview from the Knowledge Production in Educational Leadership (KPEL) project, and I would also like to thank the ESRC for funding this project (RES-000-23-1 I92).

\section{Notes on contributor}

Helen Gunter is professor of Educational Policy in The Manchester Institute of Education, University of Manchester, UK, and is an Academician of the Academy of Social Sciences. She co-edits the Journal of Educational Administration and History. Her work focuses on education policy and knowledge-production in the field of school leadership. Her most recent books are: Leadership and the Reform of Education published in 2012 by Policy Press, and Educational Leadership and Hannah Arendt published in 2014 by Routledge.

\section{References}

Angus, L. 1994. "Sociological Analysis and Education Management: The Social Context of the Self-Managing School." British Journal of Sociology of Education I5 (I): 79-9I.

Apple, M. W., ed. 20I0. Global Crises, Social Justice and Education. New York: Routledge.

Ball, S. J. 1981. Beachside Comprehensive: A Case Study of Secondary Schooling. Cambridge: Cambridge University Press.

Ball, S. J., ed. 1984. Comprehensive Schooling: A Reader. Lewes: Falmer Press.

Ball, S. J. 1987. The Micro-Politics of the School: Towards a Theory of School Organization, London. London: Routledge.

Ball, S. J. 1990a. Politics and Policymaking in Education: Explorations in Policy Sociology. London: Routledge.

Ball, S. J., ed. 1990b. Foucault and Education London: Routledge.

Ball, S. J. 1990c. "Management as Moral Technology: A Luddite Analysis." In Foucault and Education, edited by S. J. Ball, 153-166. London: Routledge.

Ball, S. J. 1993. "Culture, Cost and Control: Self-Management and Entreprenuerial Schooling in England and Wales." In A Socially Critical View of the Self-Managing School, edited by J. Smyth, 63-82. London: Falmer.

Ball, S. J. 1994a. Education Reform: A Critical and Post-Structural Approach. Buckingham: Open University Press.

Ball, S. J. 1994b. "Guest Editorial. At the Cross-Roads: Education Policy Studies." British Journal of Educational Studies 42 (I): I-5.

Ball, S. J. 1994c. "Political Interviews and the Politics of Interviewing." In Researching the Powerful in Education, edited by G. Walford, 96-II5. London: Routledge.

Ball, S. J. 1994d. "Some Reflections on Policy Theory: A Brief Response to Hatcher and Troyna." Journal of Education Policy 9 (2): 17|-182.

Ball, S. J. 1995. "Intellectuals or Technicians? The Urgent Role of Theory in Educational Studies." British Journal of Educational Studies 43 (3): 255-27I.

Ball, S. J. 1997. "Policy Sociology and Critical Social Research: A Personal Review of Recent Education Policy and Policy Research." British Education Research Journal 23 (3): 257-274.

Ball, S. J. 1998. "Educational Studies, Policy Entrepreneurship and Social Theory." In School Effectiveness For Whom? edited by R. Slee, G. Weiner, and S. Tomlinson, 70-83. London: Falmer Press.

Ball, S. J. 200 la. "Performativities and Fabrications in the Education Economy." In The Performing School, edited by D. Gleeson and C. Husbands, 210-226. London: RoutledgeFalmer.

Ball, S. J. $200 \mathrm{lb}$. "Labour, Learning and the Economy. A 'Policy Sociology' Perspective." In Taking Education Really Seriously, Four Years Hard Labour, edited by M. Fielding, 45-56. London: RoutledgeFalmer.

Ball, S. J. 2003a. Class Strategies and the Education Market, the Middle Classes and Social Advantage. London: RoutledgeFalmer.

Ball, S. J. 2003b. "The Teacher's Soul and the Terrors of Performativity." Journal of Education Policy 18 (2): $215-228$.

Ball, S. J. 2004a. "Performativities and Fabrications in the Education Economy." In The RoutledgeFalmer Reader in Sociology of Education, edited by S. J. Ball, 143-155. Abingdon: RoutledgeFalmer. 
Ball, S. J. 2004b. Education for Sale! The Commodification of Everything? The Annual Education Lecture, Universidade de Santiago de Compostella. Accessed January 15, 2013. http://firgoa.use.es/dropal/ node/ 43424

Ball, S. J. 2005. "Radical Policies, Progressive Modernization and Deepening Democracy: The Academies Programme in Action." Forum 47 (2\&3): 215-222.

Ball, S. J. 2006. Education Policy and Social Class. The Selected Works of Stephen Ball. Abingdon: Routledge.

Ball, S. J. 2007. Education PLC. Abingdon: Routledge.

Ball, S. J. 2008a. The Education Debate. Bristol: The Policy Press.

Ball, S. J. 2008b. "The Legacy of ERA, Privatization and the Policy Ratchet." Educational Management, Administration and Leadership 36 (2): 185-199.

Ball, S. J. 2008c. "New Philanthropy, New Networks and New Governance in Education." Political Studies 56 (4): 747-765.

Ball, S. J. 2009. "Beyond Networks? A Brief Response to 'Which Networks Matter in Education Governance'." Political Studies 57 (3): 688-69I.

Ball, S. J. 2010. "New Voices, New Knowledges and the New Politics of Education Research: The Gathering of the Perfect Storm?" European Educational Research Journal 9 (2): 124-137.

Ball, S. J. 201 Ia. "Academies, Policy Networks and Governance." In The State and Education Policy: The Academies Programme, edited by H. M. Gunter, I46-158. London: Continuum.

Ball, S. J. 20Ilb. "A New Research Agenda for Educational Leadership and Policy." Management in Education 25 (2): 50-52.

Ball, S. J. 2012. Global Education Inc. New Policy Networks and the Neo-Liberal Imaginary. Abingdon: Routledge.

Ball, S. J. 2013. Foucault, Power and Education. New York: Routledge.

Ball, S. J., and S. Exley. 2010. "Making Policy with 'Good Ideas': Policy Networks and the 'Intellectuals' of New Labour." Journal of Education Policy 25 (2): 15I-169.

Ball, S. J., and I. F. Goodson, eds. 1985. Teachers' Lives and Careers. Lewes: Falmer Press.

Ball, S. J., and C. Junemann. 2012. Networks, New Governance and Education. Bristol: The Policy Press.

Ball, S. J., M. Maguire, A. Braun, K. Hoskins, and J. Perryman. 2012. How Schools Do Policy, Policy Enactments in Secondary Schools. Abingdon: Routledge.

Barber, M. 1996. The Learning Game, Arguments for a Learning Revolution. London: Victor Gollancz.

Barber, M. 2007. Instruction to Deliver. London: Politico's Publishing.

Bourdieu, P. 2000. Pascalian Meditations. Cambridge: Policy Press.

Bowe, R., and S. J. Ball. 1992. "Doing What Should Come Naturally: An Exploration of LMS in One Secondary School." In Local Management of Schools Practice, edited by G. Wallace, 36-52. Clevedon: Multi-Lingual Matters.

Bowe, R., S. J., Ball, and A., Gold. 1992. Reforming Education \& Changing Schools: Case Studies in Policy Sociology. London: Routledge.

Chakrabortty, A. 2012. "Economics has Failed us: But Where are the Fresh Voices?" Accessed May 2. http://www.guardian.co.uk/commentisfree/20 I/apr/I6/economics-has-failed-us-alternative-voices/ print

Creemers, B., J. Scheerens, and D. Reynolds. 2000. "Theory Development in School Effectiveness Research." In The International Handbook of School Effectiveness Research, edited by C. Teddlie and D. Reynolds, 283-298. London: RoutledgeFalmer.

Day, C., A. Harris, M. Hadfield, H. Tolley, and J. Beresford. 2000. Leading Schools in Times of Change. Buckingham: Open University Press.

DfEE. 1998. Teachers: Meeting the Challenge of Change. London: DfEE.

Evans, R. 2013. "The Headteachers Who Just Said No." The Guardian, 12th February 2013, 34.

Gamble, A. 2012. "Have the Social Sciences Failed Us"? Accessed May 2. http://www.britac.ac.uk/policy perspectives/Haves-the-social-sciences-failed-us/cfm

Gewirtz, S. 2002. The Managerial School. London: Routledge.

Gewirtz, S., S. J. Ball, and R. Bowe. 1993. "Values and Ethics in the Education Market Place: The Case of Northwark Park." International Studies in Sociology of Education 3 (2): 233-254.

Gewirtz, S., S. J. Ball, and R. Bowe. 1995. Markets Choice and Equity in Education. Buckingham: Open University Press.

Goodson, I. F., and S. J. Ball, eds. 1984. Defining the Curriculum: Histories and Ethnographies. Lewes: Falmer Press.

Grace, G. 1995. School Leadership: Beyond Educational Management. London: The Falmer Press.

Gunter, H. M. 1997. Rethinking Education: The Consequences of Jurassic Management. London: Cassell. 
Gunter, H. M. 2006a. Interview with S. J. Ball. Unpublished.

Gunter, H. M. 2006b. "Knowledge Production in the Field of Educational Leadership: A Place for Intellectual Histories." Journal of Educational Administration and History. 38 (2): 20I-2I5.

Gunter, H. M. 2012a. Leadership and the Reform of Education. Bristol: The Policy Press.

Gunter, H. M. 20I2b. "Intellectual Work and Knowledge Production." In Hard Labour? Academic Work and the Changing Landscape of Higher Education, edited by T. Fitzgerald, J. White, and H. M. Gunter, 23-40. Bingley: Emerald Group.

Gunter, H. M., D. Hall, and J. Bragg. 2013. "Distributed Leadership: A Study in Knowledge Production." Educational Leadership, Management and Administration 4I (5): 556-58I.

Gunter, H. M., C. Raffo, D. Hall, A. Dyson, L. Jones, and A. Kalambouka. 2010. "Policy and the Policy Process." In Education and Poverty in Affluent Countries, edited by C. Raffo, A. Dyson, H. M. Gunter, D. Hall, L. Jones, and A. Kalambouka, 163-176. London: Routledge.

Hargreaves, D. H., and D. Hopkins. 199I. The Empowered School. London: Cassell.

Harris, A. 2008. Distributed School Leadership. Abingdon: Routledge.

Hatcher, R., and B. Troyna. 1994. "The 'Policy Cycle': A Ball by Ball Account.” Journal of Education Policy 9 (2): $155-170$.

Hopkins, D. 200I. 'Think Tank' Report to Governing Council. Nottingham: NCSL.

Hopkins, D. 2007. Every School a Great School, Realizing the Potential of System Leadership. Maidenhead: OUP.

Hoyle, E. 1986. "The Management of Schools: Theory and Practice." In World Yearbook of Education 1986: The Management of Schools, edited by E. Hoyle, and A. McMahon. London: Kogan Page.

Leithwood, K., C. Day, P. Sammons, A. Harris, and D. Hopkins. 2006. Seven Strong Claims about Successful School Leadership. Nottingham: NCSL.

Leithwood, K., D. Jantzi, and R. Steinbach. 1999. Changing Leadership for Changing Times. Buckingham: OUP.

Maguire, M., and S. J. Ball. 1994a. "Researching Politics and the Politics of Research: Recent Qualitative Studies in the UK." Qualitative Studies in Education 7 (3): 269-285.

Maguire, M., and S. J. Ball. 1994b. "Discourses in Educational Reform in the United Kingdom and the USA and the Work of Teachers." British Journal of in-Service Education 20 (I): 5-16.

Maguire, M., S. J. Ball, and A. Braun. 20I2. "What Ever Happened to ...? 'Personalised Learning' as a Case of Policy Dissipation." Journal of Education Policy 28 (3): 322-338.

Millar F. 2013. "The Unstoppable Rise of the Heads' Routable." The Guardian, 4th February 2013. Accessed February 5. http://www.guardian.co.uk/education/2013/feb/04/ebc-headteachers-on-twitter-baccalaureate

Ozga, J. 2000. Policy Research in Educational Settings. Buckingham: OUP.

Ozga, J. 2009. "Governing Education through Data in England: from Regulation to Self-Evaluation." Journal of Education Policy 24 (2): 149-162.

Reay, D., and S. J. Ball. 2000. "Essentials of Female Management: Women's Ways of Working in the Education Marketplace?" Educational Management and Administration 28 (2): 145-158.

Reynolds, D., P. Sammons, L. Stoll, M. Barber, and J. Hillman. 1996. "School Effectiveness and School Improvement in the United Kingdom." School Effectiveness and School Improvement 7 (2): I33-158.

Rizvi, F., and B. Lingard. 2010. Globalizing Education Policy. London: Routledge.

Sammons, P., C., Chapman, D. Muijs, C. Day, Q. Gu, A. Harris, A. Kelly, and D. Reynolds. 2010. "Evidence Shows We Can Effect Change." Times Educational Supplement, 12th March 2010. Accessed June 25. www.tes.co.uk/article.aspx? storycode $=6038668$

Stoll, L., and D. Fink. 1996. Changing Our Schools. Buckingham: OUP.

Teddlie, C., and D. Reynolds, eds. 2000. The International Handbook of School Effectiveness Research. London: RoutledgeFalmer.

Teddlie, C., and D. Reynolds. 200I. "Countering the Critics: Responses to Recent Criticisms of School Effectiveness Research." School Effectiveness and School Improvement I2 (I): 4I-82.

Young, M. F. D. 2008. Bringing Knowledge Back In. Abingdon: Routledge. 